Tarbawi: Jurnal Ilmu Pendidikan p-ISSN:1858-1080 | e-ISSN: 2615-6547

Vol. 16, No. 2, Desember 2020, 139 - 147

\title{
Pengembangan Modul Pembelajaran Matematika Berbasis Peta Pikiran pada Materi Peluang
}

\author{
Trisna Rukhmana, Loria Wahyuni \\ STKIP Muhammadiyah Sungai Penuh \\ E-mail: trisnarukhmana29@gmail.com
}

\begin{abstract}
Abstrak. Penelitian ini bertujuan untuk mengembangan modul pembelajaran matematika berbasis peta pikiran yang valid, praktis dan efektif pada materi peluang untuk peserta didik kelas XI. Jenis penelitian ini adalah penelitian pengembangan (research and thedevelopment) dengan model 4-D (define, desain, develop, desemenaid). Subjek penelitian ini adalah peserta didik kelas XI pada salah satu SMA di Sungai Penuh. Data penelitian dikumpulkan menggunakan lembar validasi, angket respon peserta didik dan guru, lembar observasi aktivitas belajar, angket motivasi peserta didik dan tes hasil belajar. Data yang diperoleh selanjutnya diolah dan dianalisis secara deskriptif. Hasil penelitian menunjukkan bahwa modul pembelajaran matematika berbasis peta pikiran pada materi peluang yang telah dikembangkan berada pada kategori valid, praktis dan efektif. Hal ini dapat dilihat dari hasil validasi modul oleh ahli dengan nilai rata-rata 76,95\% termasuk kategari valid dan hasil uji kepraktisan modul oleh peserta didik nilai rata-rata $82,72 \%$ termasuk kategori sangat praktis dan guru dengan nilai rata-rata 75,3\% termasuk kategori praktis. Selain itu, hasil uji efektivitas modul berdasarkan data aktivitas peserta didik menunjukkan terjadi peningkatan yaitu pertemuan I, II dan III dengan rata-rata aktivitas peserta didik 70\%, 72,22 dan 81,11\%. Angket motivasi berada pada kriteria sangat termotivasi dengan rata-rata persentase motivasi peserta didik dalam belajar adalah $80,8 \%$. Sedangkan hasil tes diperolah $88,9 \%$ artinya tingkat kelulusan peserta didik lebih dari $75 \%$. Sehingga dapat disimpulkan bahwa modul pembelajaran matematika berbasis peta pikiran pada materi peluang layak dijadikan sebagai bahan ajar bagi pesrta didik kelas XI.
\end{abstract}

Kata Kunci: Modul Pembelajaran Matematika, Pengembangan, Peta Pikiran, Materi Peluang

\begin{abstract}
This study aims to develop a mind map-based of mathematics learning module that is valid, practical and effective on the probability materials for eleventh-grade students. This type of research is research and development (R\&D) design with a 4-D model (Define, Design, Develop, and Disseminate). The subjects of this study were eleventh-grade students in one of junior high school in Sungai Penuh. The research data were collected using validation sheets, students' and teachers' response on questionnaires, learning activity observation sheets, students' motivation questionnaires and learning outcomes tests. The data obtained were then processed and analyzed descriptively. The results showed that the mind map-based mathematics learning module on the opportunity material that had been developed was in the valid, practical and effective category. This can be seen from the results of module validation by experts with an average value of $76,95 \%$ which is categorized as valid and the results of the practicality of the module by students with an average value of $82,72 \%$ which is categorized as very practical, then the results of the practicality of the module by teacher with the average value of 75,3\% which is categorized as practical. Also, the results of the module effectiveness test, based on the activity data of students, there is an increase, namely meetings I, II and III with an average student activity of 70\%, 72.22 and $81.11 \%$. The motivation questionnaire is in the motivated criteria with an average percentage of students' motivation in learning is $80,8 \%$. While the test resultis $88.89 \%$, which means the students pass rate was more than $75 \%$. Finally, the conclusion is the mind map-based of mathematics learning module on the opportunity material is suitable as teaching material for eleventh-grade students.
\end{abstract}

Keywords: Mathematics Learning Module, Development, Mind Maps, Probability Materials 


\section{PENDAHULUAN}

Kualitas pendidikan ini dianggap penting karena sangat menentukan gerak laju pembangunan di negara manapun juga. Oleh karena itu, hampir semua negara di dunia senantiasa berusaha untuk meningkatkan kualitas pendidikan sebagai upaya peningkatan kualitas hidup masyarakat termasuk Indonesia. Berbagai upaya telah dilakukan oleh pemerintah untuk meningkatkan pencapaian hasil belajar yang optimal diantaranya penyempurnaan kurikulum, memberikan pelatihan, lokarya dan seminar kepada guru-guru. Guru diharapkan dapat menciptakan suasana belajar yang dapat melibatkan peserta didik secara aktif. Selain itu, ketepatan metode, pendekatan dan teknik penyajian akan memungkinkan peserta didik untuk mengembangkan kualitas dan potensi yang dimilikinya, sehingga peserta didik merasa tertarik untuk mengikuti pelajaran yang disajikan.

Namun kenyataan dilapangan, hasil belajar peserta didik masih ada yang belum mencapai Kriteria Ketuntasan Minimum (KKM). Berdasarkan hasil observasi yang dilakukan di SMA N 5 Sungai Penuh diketahui bahwa pada proses pembelajaran matematika peserta didik belum memahamimateri pembelajaran dengan baik, kemampuanpeserta didik dalam mengembangkan konsep materi pelajaran matematika dan menyelesaikanmasalah berupa soal-soal latihan yang diberikan guru masih kurang, peserta didik kurang berani untuk bertanya jika ada materi yang belum dipahami, peserta didik juga belum bisa mengembangkan ide-ide pemikiran mereka secara kreatif. Hal ini berarti kemampuan berpikir kreatif dan kritis peserta didik belum berkembang secara optimal.

Selain faktor diatas, penyebab permasalahan juga terdapat pada bahan ajar yang digunakan oleh guru. Guru hanya menggunakan buku teks di perpustakaan sekolah yang jumlahnya juga terbatas dan LKS yang didapatkan dari distributor yang datang ke sekolah yang belum tentu sesuai dengan karakteristik peserta didik. Jadi, bahan ajar yang digunakan dalam pembelajaran belum mampu mengakomodasikan kebutuhan siswa untuk belajar aktif dan berpikir kreatif serta kritis dalam proses pembelajaran. Apabila permasalahan di atas tetap dibiarkan maka akan berdampak buruk pada hasil belajar siswa. Hal ini bisa dilihat dari hasil belajar mata pelajaran matematika yang diperoleh siswa. Oleh karena itu, guru perlu pengembangan bahan ajar yang dapat membantu meningkatkan pemahaman dan motivasi peserta didik, serta bahan ajar yang dapat merangsang peserta didik untuk bisa lebih aktif dan berpikir kritis serta terarah. Salah satunya dengan menggunakan bahan ajar berupa modul.

Berdasarkan analisis kebutuhan guru, maka untuk meningkatkan pembelajaran matematika perlu dikembangkan bahan ajar berupa modul dengan variasi yang berbeda, salah satunya dengan pengembangan modul berbasis peta pikiran. Tjiptiany, As'ari, \& Muksar (2016) mengatakan bahwa modul adalah bahan ajar yang disusun secara sistematis dan menarik yang mencakup isi materi, metode, danevaluasi yang dapat digunakan secara mandiri. Sedangkan menurut Russel dalam (Haryanti \& Saputro, 2016) "sistem pembelajaran sistem modul akan menjadikan pembelajaran lebih efisisn, efektif dan relevan". Jadi, modul adalah seperangkat bahan ajar yang disajikan secara sistematis sehingga penggunanya dapat belajar dengan tanpa bantuan seorang fasilitator/guru (Betyka, Putra, \& Erita, 2019). Dengan demikian maka sebuah modul harus dapat dijadikan sebuah bahan ajar sebagai pengganti fungsi guru.

Menurut Aprinawati (2018) beberapa siswa mengalami kesulitan berkonsentrasi ketika mengerjakan tugas. Ini terjadi dikarenakan catatan ataupun ingatan belum teratur. Untuk itu, dibutuhkan suatu alat untuk membantu otak berpikir secara teratur. Untuk mengingat kembali dengan cepat materi yang telah kita pelajari sebaiknya meniru cara kerja otak dalam bentuk peta pikiran. Selanjutnya Widura (2013) menjelaskan mind map (peta pikiran) sebagai system belajar dan berfikir yang menggunakan kedua belahan otak sesuai dengan cara kerja alaminya, mengeluarkan seluruh potensi dan kapasitas otak yang masih tersembunyi, dan mencerminkan apa yang terjadi secara internal didalam otak saat belajar dan berfikir serta mencerminkannya secara visual. 
Dengan peta pikiran, siswa terbantu dalam memahami konsep matematika dan menyelesaikan masalah matematika. Oleh sebab itu, penelitian ini dilakukan untuk mengembangkan modul berbasis peta pikiran yang diharapkan dapat memberikan bantuan pada siswa dalam pembelajaran matematika terutama ditingkat SMA pada materi Peluang.

\section{METODOLOGI}

Penelitian ini merupakan penelitian pengembangan (research and the development). Pengembangan modul pembelajaran matematika berbasis peta pikiran yang valid, praktis, dan efiktif ini menggunakan model Four-D (4-D), yang dikemukakan oleh Thiagrajan (1974). Model pengembangan 4-D terdiri dari 4 tahap yaitu Define (pendefinisian), Design (perancangan), Develop (pengembangan), dan disseminate (penyebaran) dilaksanakan secara terbatas (skala kecil). Subjek penelitian adalah kelas XI IPA SMA 5 Negeri Sungai Penuh. Model pengembangannya dapat dilihat pada Gambar 1.

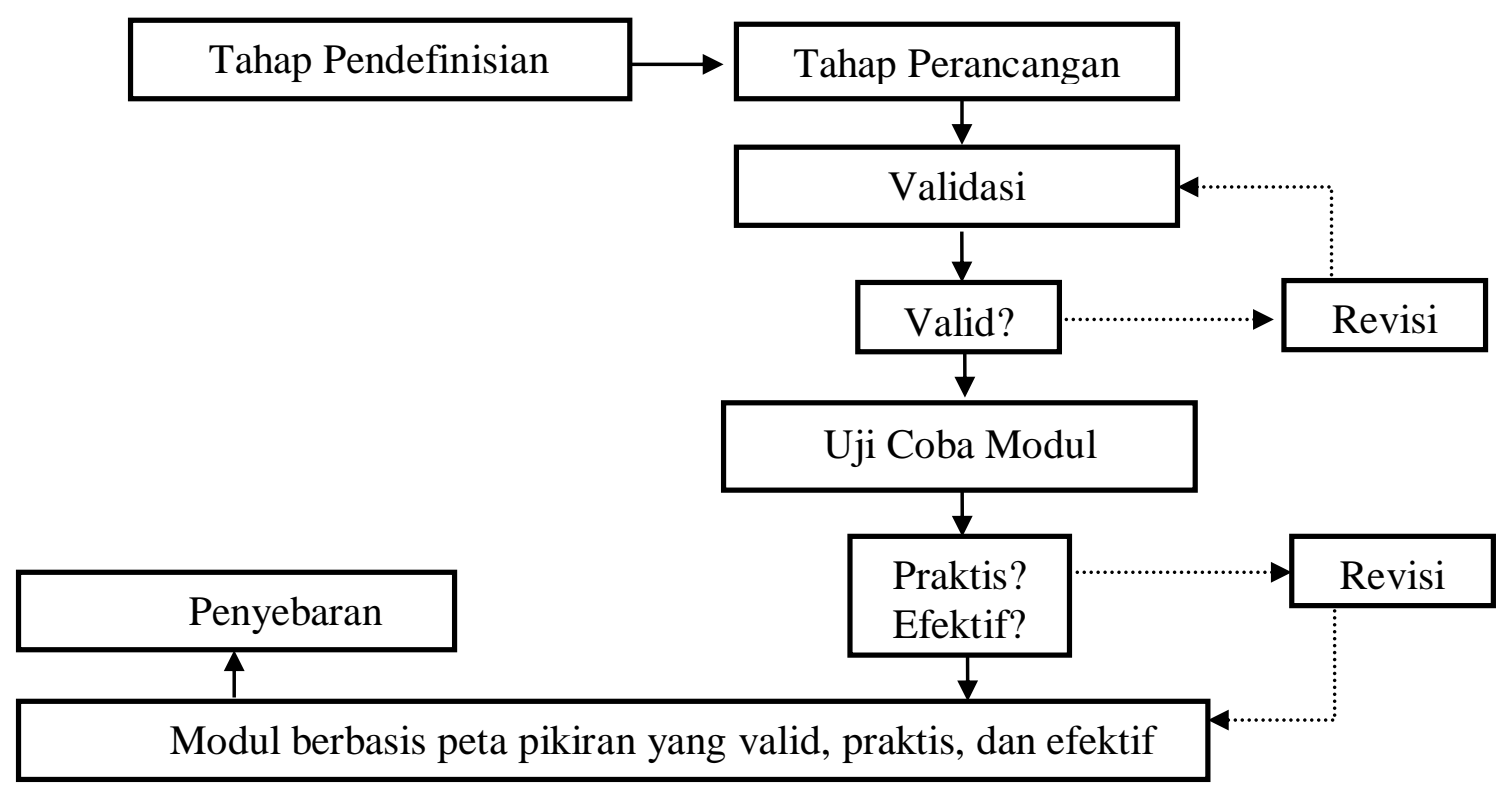

Gambar 1. Bagan Prosedur Penelitian Pengembangan Modul Pembelajaran Matematika Berbasis Peta Pikiran Model 4-D

Analisis data yang dilakukan dalam penelitian ini berupa analisis kevalidan, Uji Praktikalitas dan uji efektivitas modul.

\section{Uji Validasi Modul}

Tingkat pencapaian kategori kevalidan modul menggunakan klasifikasi dengan ketentuan pada Tabel 1.

Tabel 1. Tingkat Pencapaian Kategori Kevalidan

\begin{tabular}{cc}
\hline Interval (\%) & Kategori \\
\hline $0-20$ & Tidak Valid \\
\hline $21-40$ & Kurang Valid \\
\hline $41-60$ & Cukup Valid \\
\hline $61-80$ & Valid \\
\hline $81-100$ & Sangat valid \\
\hline
\end{tabular}




\section{Analisis Uji Praktikalitas Modul}

Pemberian nilai praktikalitas dengan kriteria pada Tabel 2.

Tabel 2. Penilaian Praktikalitas

\begin{tabular}{cc}
\hline Interval (\%) & Kategori \\
\hline $0-20$ & Tidak Praktis \\
\hline $21-40$ & Kurang Praktis \\
\hline $41-60$ & Cukup Praktis \\
\hline $61-80$ & Praktis \\
\hline $81-100$ & Sangat Praktis \\
\hline
\end{tabular}

\section{Analisis Uji Efektivitas Modul}

\section{Analisis Motivasi Belajar Peserta Didik}

Data tentang motivasi belajar siswa terhadap kegiatan pembelajaran dianalisis dengan menggunakan persentase (\%) Zafri (2008).

$$
\text { Persentase }=\frac{\text { skor jawaban masing }- \text { masing item }}{\text { jumlah skor ideal item }} \times 100 \%
$$

Data persentase motivasi belajar siswa yang diperoleh dilakukan pengelompokan sesuai kriteria pada Tabel 3 Riduwan (2012).

Tabel 3. Kriteria Tingkat Motivasi Belajar

\begin{tabular}{cc}
\hline Interval (\%) & Kategori \\
\hline $0-20$ & Sangat Kurang Termotivasi \\
\hline $21-40$ & Kurang Termotivasi \\
\hline $41-60$ & Cukup Termotivasi \\
\hline $61-80$ & Termotivasi \\
\hline $81-100$ & Sangat Termotivasi \\
\hline
\end{tabular}

\section{Analisis Aktivitas Belajar siswa}

Data tentang aktivitas belajar siswa terhadap kegiatan pembelajaran dianalisis dengan menggunakan persentase (\%) Zafri (2008).

$$
P=\frac{f}{N} \times 100 \%
$$

Data persentase aktivitas belajar siswa yang diperoleh dilakukan pengelompokan sesuai kriteria pada Tabel 4 Riduwan (2012).

Tabel 4. Kriteria Tingkat Aktivitas Belajar

\begin{tabular}{cc}
\hline Interval (\%) & Kategori \\
\hline $0-20$ & Sangat kurang aktif \\
\hline $21-40$ & kurang aktif \\
\hline $41-60$ & Cukup aktif \\
\hline $61-80$ & Aktif \\
\hline $81-100$ & Sangat aktif
\end{tabular}

\section{Analisis Hasil Belajar}

Untuk menentukan ketuntasan belajar siswa dapat dihitung dengan menggunakan persamaan persentase (Trianto, 2010).

$$
\mathrm{KB}=\frac{\mathrm{r}}{\mathrm{Tt}} \times 100 \%
$$


Data persentase keberhasilan belajar siswa yang diperoleh dilakukan pengelompokan sesuai kriteria pada Tabel 5 Riduwan (2012).

Tabel 5. Kriteria dan Tingkat Keberhasilan Hasil Belajar

\begin{tabular}{ccc}
\hline Kriteria & Tingkat Keberhasilan & Persentase \\
\hline Sedikit sekali & Tidak berhasil & $1 \leq \mathrm{KB}<25$ \\
\hline Sedikit & Kurang berhasil & $25 \leq \mathrm{KB}<50$ \\
\hline Banyak & Berhasil & $50 \leq \mathrm{KB}<75$ \\
\hline Banyak sekali & Sangat berhasil & $75 \leq \mathrm{KB}<100$ \\
\hline
\end{tabular}

\section{TEMUAN}

Penelitian dilakukan ini terdiri dari 4 tahapan, yaitu tahap pendefinisian (define), tahap perancangan (desain), tahap pengembangan (develop) dan tahap penyebaran. (desemenaid). Berikut ini dikemukakan hasil setiap tahapan penelitian.

\section{Tahap Pendefinisian (define)}

Hasil dari tahap pendefinisian bertujuan untuk melihat gambaran umum berkaitan dengan pembelajaran matematika di SMAN 5 Sungai Penuh, kemudian menganalisis permasalahannya (Putra \& Syarifuddin, 2018). Berdasarkan hasil analisis, dapat diidentifikasi bahwa siswa masih banyak yang belum sepenuhnya memahami materi peluang, sehingga perlu adanya bahan ajar atau media pendukung agar siswa termotivasi dalam belajar, mampu belajar secara mandiri,dan lebih variatif dalam belajar yang dapat membantu mensimulasikan konsep pada materi peluang sehingga mempermudah pemahaman sekaligus membuat siswa tertarik pada materi yang sedang ajarkan.

\section{Tahap Perancangan (desain)}

Hasil dari tahap perancangan (design) ini adalah merancang modul matematika berbasis peta pikiran untuk digunakan siswa sebagai tuntunan/bahan ajar dalam mempelajari materi peluang. Penyusunan modul diawali dengan mencari berbagai referensi yang dibutuhkan (Putra, Syarifuddin, \& Zulfah, 2018). Hal ini termasuk dalam analisis kebutuhan. Setelah itu, melakukan perancangan kerangka (outline) modul, dan mendesainnya agar memiliki tampilan yang menarik. Penyusunan kerangka modul disesuaikan dengan pembelajaran yang digunakan, yaitu berbasis peta pikiran. Modul yang dirancang memiliki format seperti modul pada umumnya, yaitu bagian pendahuluan, kegiatan belajar dan evaluasi. Akan tetapi, pengembangan ketiga bagian tersebut diintegrasikan dengan langkah-langkah dan prinsip berbasis peta pikiran.

\section{Tahap Pengembangan (develop)}

\section{Validasi Modul}

Modul pembelajaran matematika berbasis peta pikiran divalidasi oleh pakar atau praktisi pendidikan sesuai dengan bidang kajiannya yang terdiri dari 2 orang validator yaitu validator ahli bahasa dan validator ahli materi. Hasil validasi modul oleh validator pada Tabel 6 .

Tabel 6. Hasil Validasi Modul oleh Validator

\begin{tabular}{ccccc}
\hline No. & Aspek yang dinilai & Jumlah Skor & Persentase (\%) & Kategori \\
\hline 1 & Didaktik & 22 & 73,3 & Valid \\
\hline 2 & Isi & 23 & 76,7 & Valid \\
\hline 3 & Penyajian & 35 & 77,8 & Valid \\
\hline 4 & Bahasa & 20 & 80 & Valid \\
\hline & Rata-rata & & $76,95 \%$ & Valid \\
\hline
\end{tabular}


Berdasarkan hasil validasi kedua validator menyatakan modul pembelajaran matematika berbasis peta pikiran pada materi peluang dengan rata-rata $76,95 \%$ berada pada kategori valid.

\section{Uji Kepraktisan}

Setelah itu dilakukan uji praktikalitas modul oleh guru dan siswa. Berdasarkan hasil uji coba praktikalitas modul oleh guru menunjukan bahwa modul pembelajaran matematika berbasis peta pikiran pada materi peluang memperoleh nilai 75,3\% menunjukkan bahwa modul dinyatakan praktis. Sedangkan hasil uji praktikalitas modul oleh siswa menunjukkan rata-rata nilai $82,72 \%$ dengan kategori sangat praktis.

\section{Uji Efektivitas Modul}

Uji efektivitas modul dilakukan dengan mengujicobakan modul pada peserta didik. Untuk pengujian efektivitas modul digunakan angket lembar observasi berupa lembar aktivitas dan angket motivasi serta tes akhir peserta didik. Hasil dari Ujicoba berupa observasi aktivitas, motivasi peserta didik dan hasil belajar peserta didik dapat dilihat pada Tabel 7.

Tabel 7. Hasil Observasi Aktivitas Siswa

\begin{tabular}{cccc}
\hline No. & Pertemuan ke- & Rata-rata Aktivitas (\%) & Kategori \\
\hline 1 & I & $70 \%$ & Aktif \\
\hline 2 & II & $72,22 \%$ & Aktif \\
\hline 3 & III & $81,11 \%$ & Sangat Aktif \\
\hline & Rata-rata & $\mathbf{7 4 , 4 \%}$ & Aktif \\
\hline
\end{tabular}

Hasil observasi aktivitas peserta didik kelas XI IPA SMA N 5 Sungai Penuh saat menggunakan modul adalah meningkat setiap pertemuan dengan rata-rata $74,4 \%$ termasuk kategoti aktif.

Tabel 8. Hasil Angket Motivasi Belajar Siswa

\begin{tabular}{clcc}
\hline No. & \multicolumn{1}{c}{ Pertemuan ke- } & Rata-Rata (\%) & Kategori \\
\hline 1 & Minat/Perhatian (Item 1-4) & 80,9 & Sangat termotivasi \\
\hline 2 & Relevansi (item 5-11) & 73,8 & Termotivasi \\
\hline 3 & Harapan/Keyakinan (item 12) & 86,7 & Sangat termotivasi \\
\hline 4 & Kepuasan (item 13-19) & 81,9 & Sangat termotivasi \\
\hline \multicolumn{2}{c}{ Rata-Rata } & $\mathbf{8 0 , 8}$ & Sangat Termotivasi \\
\hline
\end{tabular}

Hasil angket motivasi belajar peserta didik dalam pembelajaran dengan menggunakan modul pembelajaran matematika berbasis peta pikiran untuk diperoleh nilai rata-rata yaitu 80,8\% dengan kategori sangat termotivasi.

Sedangkan hasil tes akhir peserta didik yang diikuti oleh 18 orang diperoleh nilai rata-rata adalah 80 . Peserta didik yang memperoleh nilai $\geq 70$ adalah 16 orang dengan persentase $88,9 \%$ dan persentase ketuntasan $80 \%$.

\section{Penyebaran}

Tahap penyebaran dilakukan secara terbatas atau dalam skala kecil yaitu pada kelas XI SMA Negeri 5 Sungai Penuh.

\section{DISKUSI}

Penelitian pengembangan ini menghasilkan sebuah bahan ajar berupa modul pembelajaran matematika berbasis peta pikiran pada materi peluang. Desain atau rancangan modul yang dikembangkan telah disesuaikan dengan struktur pembuatan modul yang diintegrasikan dengan 
berbasis peta pikiran. Untuk mendapatkan model modul yang berkualitas, maka diperlukan uji validasi, praktikalitas, dan efektivitas dari modul tersebut.

Berdasarkan hasil validasi oleh validator, modul pembelajaran matematika berbasis peta pikiran pada materi peluang dinyatakan valid setelah memenuhi 4 aspek yaitu aspek didaktik, isi, penyajian, dan bahasa dengan rata-rata $76,95 \%$. Modul pembelajaran matematika berbasis peta pikiran sudah memenuhi aspek didaktik karena materi dalam modul menunjang pencapaian kompetensi dasar, modul pembelajaran matematika berbasis peta pikiran mendukung pemahaman konsep, memuat gambar yang membantu siswa memahami materi, modul sesuai dengan kompetensi inti dan kompetensi dasar dalam kurikulum pembelajaran matematika.

Berdasarkan hasil uji coba praktikalitas modul oleh guru menunjukan bahwa modul pembelajaran matematika berbasis peta pikiran pada materi peluang memperoleh nilai $75,3 \%$ menunjukkan bahwa modul dinyatakan praktis. Hal ini, menunjukkan bahwa dengan adanya modul pembelajaran matematika berbasis peta pikiran pada materi peluang dapat mempermudah guru dalam proses pembelajaran serta memiliki waktu yang efisien. Modul dapat memfasilitasi siswa untuk belajar mandiri, membangun konsep sendiri dan mendapat kemudahan dalam mempelajari setiap kompetensi yang harus dikuasai. Sedangkan hasil uji praktikalitas modul oleh siswa menunjukkan rata-rata nilai $82,72 \%$ dengan kategori sangat praktis. Dengan demikian ratarata praktiklitas modul pembelajaran matematika berbasis peta pikiran pada materi peluang oleh siswa dinyatakan sangat praktis karena modul dapat meningkatkan minat siswa dalam belajar. Modul praktis digunakan dalam proses pembelajaran karena membantu pemahaman siswa terhadap materi peluang.

Siswa merasa tertarik menggunakan modul pembelajaran matematika berbasis peta pikiran karena di dalam modul terdapat petunjuk penggunaan yang jelas dan mudah dipahami. Dalam modul dilengkapi peta pikiran yang dapat membantu siswa menemukan konsep dengan mudah. Modul disajikan menarik karena modul disajikan berwarna, hal ini dapat menimbulkan ketertarikan pada siswa untuk mempelajari materi yang ada didalam modul karena mata akan lebih cepat fokus dengan warna.

Selain itu pembelajaran dengan menggunakan modul pembelajaran matematka berbasis peta pikiran memunculkan ketertarikan siswa untuk belajar matematika, karena modul yang dikembangkan menggunakan bahasa yang mudah dipahami. Hal ini sesuai dengan yang diungkapkan Bondono dalam Lia (2014) bahwa dengan menggunakan modul dengan bahasa yang baik membantu siswa lebih cepat memahami matri, merasa senang, santai, dan tidak merasa tegang dalam mengukuti pembelajaran.

Berdasarkan data aktivitas 18 orang siswa yang telah mengikuti proses pembelajaran dengan menggunakan modul pembelajaran matematika berbasis peta pikiran terlihat aktivitas siswa umumnya melakukan aktivitas yang berbeda dengan rata-rata $74,4 \%$. Hal ini menunjukkan bahwa siswa aktif dalam pembelajaran dan kelas tidak menjadi membosankan. Aktivitas siswa selama proses pembelajaran merupakan salah satu indikator adanya keinginan siswa untuk belajar. Aktivitas siswa yang diamati selama penelitian adalah membaca modul, bertanya kepada guru atau pada siswa lain, mendengar penjelasan guru, mengerjakan latihan yang ada pada modul, dan menanggapi serta menjawab pertanyaan dengan lisan.

Dari segi motivasi rata-rata persentase yang diperoleh adalah 80,8\% dengan kategori sangat termotivasi. Hal ini berarti siswa memiliki minat yang sangat tinggi dalam menggunakan modul. Tingginya minat siswa dalam pembelajran disebabkan modul yang disajikan sangat menarik bagi siswa. Hal ini didukung oleh pendapat Bernand dalam Sardiman (2001) yang menyatakan bahwa minat tidak timbul secara tiba-tiba, melainkan timbul akibat dari partisipasi, pengalaman, kebiasaan pada waktu belajar atau kerja. Oleh karena itu, yang penting bagaimana menciptakan kondisi yang membangkitkan minat belajar siswa dalam pembelajaran, salah satunya dengan menggunakan bahan ajar berupa modul pembelajaran matematika berbasis peta pikiran. 
Tes hasil belajar digunakan untuk mengetahui keefektifan proses pembelajaran menggunakan modul pembelajaran matematika berbasis peta pikiran pada materi peluang. Berdasarkan hasil tes untuk materi peluang pada siswa kelas XI IPA SMA Negeri 5 Sungai Penuh data menunjukkan bahwa dari 18 siswa yang mengikuti proses pembelajaran dengan menggunakan modul pembelajaran matematika berbasis peta pikiran diperoleh nilai rata-rata 80 . Hal ini berarti $88,89 \%$ siswa yang mencapai kelulusan di atas 75\%. Dengan demikian pembelajaran dengan menggunakan modul pembelajaran matematika berbasis peta pikiran dapat dikatakan sangat berhasil dalam mencapai ketuntasan hasil belajar siswa. Dari uraian di atas menunjukkan bahwa modul pembelajaran matematika berbasis peta pikiran yang dikembangkan memudahkan siswa dalam memahami materi pembelajaran, sehingga hasil belajar siswa menjadi lebih optimal.

\section{SIMPULAN}

Modul pembelajaran matematika berbasis peta pikiran pada materi peluang yang telah dikembangkan mempunyai validitas dengan kategori sangat valid, praktikalitas dengan kategori sangat praktis dan efektivitas dengan kategori sangat efektif. Hal ini menunjukan bahwa dengan adanya modul pembelajaran matematika berbasis peta pikiran pada materi peluang dapat mempermudah guru dalam proses pembelajaran serta memiliki waktu yang efisien. Pada dasarnya hal ini juga dapat memberikan gambaran dalam meningkatkan kualitas pembelajaran. Selain itu dapat membuat pembelajaran pada materi peluang menjadi lebih mudah, dan efektif serta dapat dijadikan indikator untuk meningkatkan kualitas proses pembelajaran. Dalam pembelajaran dengan menggunakan modul pembelajaran matematika berbasis peta pikiran, tentu perlu memperbanyak modul sebagai bahan ajar.

\section{REFERENSI}

Ariani, S., Hartono, Y., \& Hiltrimartin, C. (2017).Kemampuan Pemecahan Masalah Matematika Siswa pada Pembelajaran matematika Menggunakan Strategi Abduktif-Deduktif di SMA NEGERI 1 Indralaya Utara. Jurnal Elemen, 3(1), 25-34.

Aprinawati, I. (2018). Penggunaan Model Peta Pikiran (Mind Mapping) untuk Meningkatkan Pemahaman Membaca Wacana Siswa Sekolah Dasar. Jurnal Basicedu, 2(1), 140-147.

Betyka, F., Putra, A., \& Erita, S. (2019). Pengembangan Lembar Aktivitas Siswa Berbasis Penemuan Terbimbing pada Materi Segitiga. JURING (Journal for Research in Mathematics Learning), 2(2), 179-189. doi:10.24014/juring.v2i2.7684

Haryanti, F., \& Saputro, B. A. (2016). Pengembangan Modul Matematika Berbasis Discovery Learning Berbantuan Flipbook Maker untuk Meningkatkan Kemampuan Pemahaman Konsep pada Materi Segitiga. Kalamatika: Jurnal Pendidikan Matematika, 1(2), 147-161.

Lia, A. (2019). Pengembangan Modul Fisiologi Tumbuhan Berorientasi Konstruktivisme Dilengkapi Peta Pikiran. Tarbawi: Jurnal Ilmu Pendidikan 15(1), 107-117

Putra, A., \& Syarifuddin, H. (2018). Analisis Kebutuhan Pengembangan Lembar Kerja Siswa Berbasis Penemuan Terbimbing Kelas VIII Sekolah Menengah Pertama. Jurnal Edukasi Matematika dan Sains, 6(1), 39-49. doi:10.25273/jems.v6i1.5327

Putra, A., Syarifuddin, H., \& Zulfah, Z. (2018). Validitas Lembar Kerja Peserta Didik Berbasis Penemuan Terbimbing dalam Upaya Meningkatkan Pemahaman Konsep dan Kemampuan Penalaran Matematis. Edumatika: Jurnal Riset Pendidikan Matematika, 1(2), 5662. doi:10.32939/ejrpm.v1i2.302

Riduwan, S. (2012). Pengantar Statistika. Bandung: ALFABETA.

Sardiman, A. M. (2001). Interaksi dan Motivasi Belajar Mengajar. Jakarta: PT. Raja Grafindo Persada Tjiptiany, E. N., As'ari, A. R., \& Muksar, M. (2016). Pengembangan Modul pembelajaran Matematika dengan Pendekatan Inkuiri untuk Membantu Siswa SMA Kelas X dalam 
Memahami materi Peluang. Jurnal Pendidikan: Teoti, Penelitian, dan Pengembangan, 1(10),1938-1942.

Trianto. (2010). Mendesain Model Pembelajaran Inovatif-Progresif: Konsep, Landasan, dan Implementasinya pada Kurikulum Tingkat Satuan Pendidikan (KTSP). Jakarta: Kencana Prenada Media Group. Widura, S. (2013). Mind Map untuk Siswa, Guru dan Orang Tua. Jakarta: Gramedia. 